\title{
Transgresiones ecfrásticas: El texto y la imagen en Los herederos de Segismundo de Schmidhuber de la Mora
}

\section{Georgina J. Whittingham}

Ecfrasis, la representación verbal de una representación visual pintura, escultura, fotografía y otras representaciones visibles de la imagen también tiene otro componente: la prosopopeya o la técnica retórica de dotar un objeto inanimado de voz o palabra. Las inscripciones en las tumbas y los títulos de las pinturas constituyen ejemplos de esta técnica ecfrástica. Como indica James Heffernan, los títulos de las pinturas por sí mismas desempeñan una de las funciones que la écfrasis casi siempre cumple: la crítica radical de la representación, cuyo ejemplo más conocido es el título que René Magritte le puso a su pintura de una pipa: Ceci n'est pas une pipe. (302-04). En contraste con la écfrasis poética o narrativa que alude a, y se articula en ausencia de la representación visual, en el teatro, que de acuerdo a Angel García Pintado es un cuadro o pintura en movimiento (Zatlin 202), la representación verbal siempre está ligada a la representación visual a través de la puesta en escena del texto verbal. La puesta en escena permite apreciar visualmente, no sólo imaginativamente, la interacción entre los aspectos visuales y verbales - es decir, la intersección de los diálogos/parlamentos de los personajes con las expresiones, los gestos, la indumentaria, el espacio escénico y la proxémica escenográfica.

La sinergia que se establece en el teatro entre el arte visual y verbal en el ámbito erudito y académico se ha caracterizado por conflictos ideológicos y divisiones genéricas. Nuestra tradición cultural centrada en el texto y en el alfabeto ha contemplado el contacto de la imagen con la palabra con sospecha y hasta hostilidad, a tal punto, como indica acertadamente Adrian Van Allen, que el arte visual como lenguaje es comprensible sólo con dificultad y gran esfuerzo. En virtud del empeño de los practicantes del arte verbal y visual para mantener sus disciplinas separadas, y evitar las intrusiones 
por parte de un medio en lo que se considera el dominio propiamente del otro, las transgresiones ecfrásticas, los géneros mixtos han permanecido al margen de las obras canónicas, $y$, con pocas excepciones, se han considerado productos de nexos impuros entre texto e imagen apropiados para el arte popular de masas - las novelas románticas ilustradas, caricaturas, revistas y los nexos visuales/verbales/textuales de los medios virtuales de representación - la televisión, el cine y los sistemas electrónicos digitales.

En vista de que la imagen y la palabra se dan cita en la puesta en escena, el teatro puede percibirse como un género transgresor. El cine mudo y otras formas de expresión artística visual como el ballet o la pantomima se acercarían más fielmente a la especificidad visual de la imagen si aceptamos la premisa oculocéntrica de que la imagen es distorsionada por la intromisión de la palabra. Un espléndido ejemplo contemporáneo basado en la estética de la imagen es el "Teatro visual" cubano que se inicia en los años ochenta. Pertenece a este género la obra ritualista afrocubana carente de texto titulada E-Motions/E-Mociones de Leandro Soto. Inspirada en el teatro de Antonin Artaud, la obra sintetiza el sentido de una imagen visual con el movimiento y otras formas sugeridas por ella. Su énfasis radica en la danza, la máscara, el movimiento, el lenguaje gestual, no en la palabra (González-Pérez 31).

Tal vez porque el teatro es un género que admite en su seno la "otredad" de la imagen y la del discurso, también es uno de los géneros aptos para la crítica interartística, y la investigación de los valores e intereses que mantienen separadas la representación verbal de la visual en nuestra cultura. Los herederos de Segimundo de Guillermo Schmidhuber de la Mora es una obra teatral contemporánea mexicana (1982) que explora conscientemente esa división mediante la meta-teatralidad escenográfica, las descripciones e interpretaciones de las esculturas de uno de los personajes de la obra y la discusión por parte de los personajes de la costumbre agrícola de atar pesadas piedras a los arados viejos, imagen que se inspira en una fotografía, titulada El arado del Roberto Ortíz Giacomán, afamado fotógrafo de Monterrey, que Guillermo Schmidhuber de la Mora vio en una exhibición cuando iniciaba la escritura de su obra. ${ }^{1}$

La acción de Los herederos de Segismundo comienza 20 años después de La vida es sueño de Calderón de la Barca y dramatiza la vida de Segismundo, de su hijo Américo y de sus sirvientes. Segismundo, el rey de Polonia, teme que su hijo Américo, un disoluto príncipe heredero, lo traicione aliándose con los monarcas rusos, y, como lo había hecho su padre, encarcela a su hijo en la torre, porque considera, como indica Denise DiPuccio, 


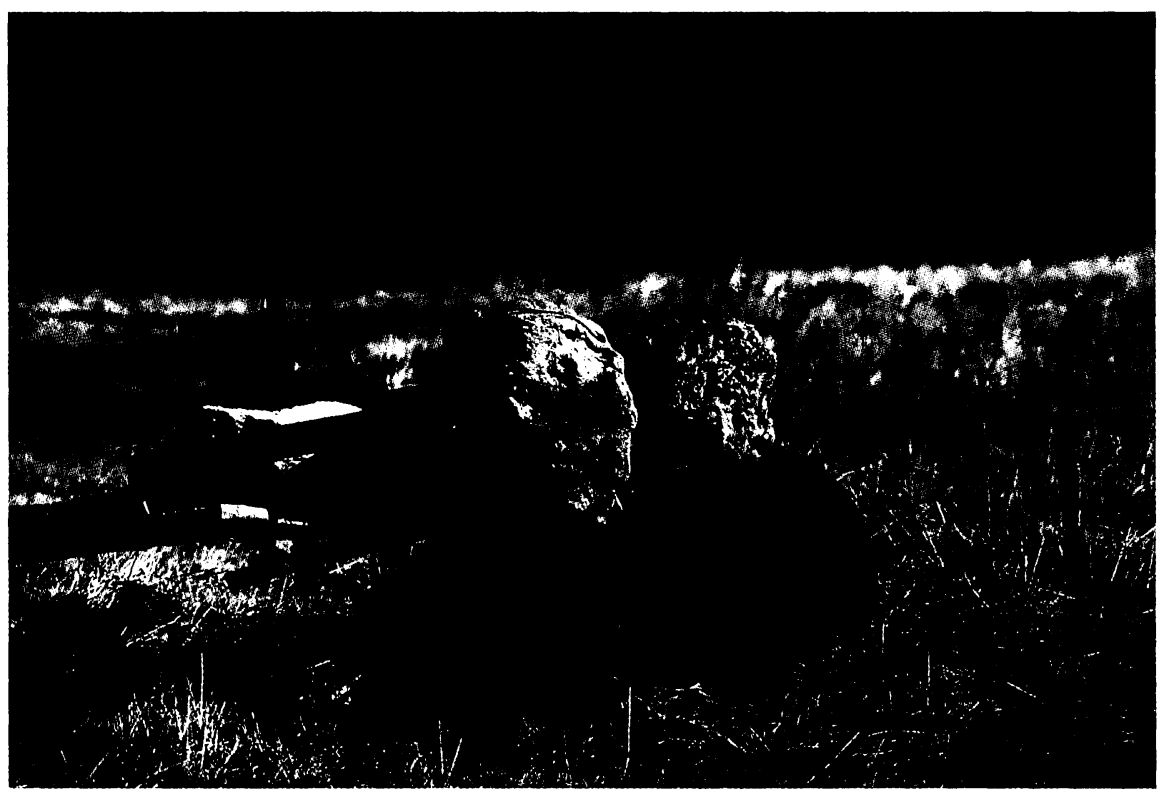

"El Arado" (México, ca. 1977) Foto de Roberto Ortiz Giacomán

exagerada y equivocadamente (45) que las acciones de su hijo, al igual que la escultura hecha por el artista de Américo que el monarca destruye son nocivas a su autoridad y a las leyes del estado absolutista monárquicocristiano. Cuando Américo finalmente asciende al trono destruye una nueva escultura del artista, una acción que simboliza la traición de los principios democráticos de su juventud. El artista como los sirvientes trabajan para efectuar cambios sociales, pero en contraste con el artista que trabaja en la corte y actúa en las escenas teatrales, los sirvientes trabajan en espacios marginales - como la cocina o la torre - y sólo ocupan un papel central, y se dirigen al público directamente, en los apartes que tienen lugar en el proscenio con el telón cerrado durante las pausas en la acción principal del drama. La obra concluye cuando Américo deja de amenazar a sus consejeros - el obispo, el artista y el científico - para que resuelvan sus problemas personales y las del estado, y decide partir para luchar contra los rusos que amenazan con anexar Polonia a sus territorios.

Las representaciones visuales - las esculturas, la fotografía, la escenografía y otras imágenes, como el espacio teatral - están dotadas de vitalidad en la obra y juegan un papel dinámico en la revisión/preservación de las convenciones socio-económicas y teatrales del siglo diecisiete para que 
futuras generaciones de trabajadores cuenten con oportunidades hasta entonces reservadas para la clase noble. El proscenio es el espacio desde el cual los sirvientes (Nicolasa la cocinera, Clarín su esposo y un soldado) dirigen la palabra al público en una serie de nueve apartes, y desde ese espacio comentan y critican lo que tiene lugar en el curso de 30 años en las escenas. El proscenio es un espacio metateatral que enmarca y subvierte la tradicional división en actos y escenas palaciegas de la comedia. Al enmarcar el espacio central de la comedia dentro de otro espacio en el cual los personajes tradicionalmente secundarios se convierten en protagonistas, salta a la vista que uno de los propósitos de la metateatralidad escenográfica es robar el escenario visual y verbalmente, por así decirlo, al monopolio hereditario teatral y económico de una minoría privilegiada para poner al alcance de los personajes marginados y económicamente necesitados derechos estéticos y económicos reservados para la clase noble: papeles protagónicos en el teatro y movilidad social, derechos a la hacienda y al honor en el campo socio-político.

El papel subversivo del proscenio se hace evidente en relación al marco de la primera escena palaciega donde Nicolasa se ve en un extremo sentada en el piso junto a Clarín. En contraposición a su activa y visible participación en los apartes, el papel virtualmente mudo, inmóvil y marginal de Nicolasa en la primera escena palaciega subraya su situación económica, social y dramáticamente servil. Los herederos de Segismundo no sólo establece una relación metateatral sino meta-pictórica con La vida es sueño. Tal vez lo más obvio de la estructura meta-pictórica, según W. J.T. Mitchell, es el de imagen de primer y segundo orden, o de centro y periferia, en el que el concepto de meta está basado (Picture Theory 42). El uso clandestino del espacio teatral de los apartes sólo tiene impacto porque se articula en el contexto y en tensión con el espacio y las convenciones del teatro y de la sociedad del siglo diecisiete de España. La imagen de segundo orden en Los herederos de Segismundo pone en duda la naturaleza y naturalidad de la ideología del objeto de primer orden, cuya representación esclaviza la imagen de segundo orden, poniendo en primer término una minoría privilegiada y relegando a segundo término e ignorando, como indica Denise DiPuccio, la capacidad estética y dramática de los personajes pobres secundarios (46).

Schmidhuber pone en escena los principios religiosos, artísticos y sociales del estado absolutista monárquico-cristiano que todavía siguen vigentes en la cultura mexicana del siglo veintiuno y manipulando la tradicional forma dramática de La vida es sueño para construir un drama política y estéticamente proletario, subvirtiendo mediante el título y la estructura visual 
y lingüística de su comedia contemporánea el concepto de herencia del poder al aplicarla a los nobles y a los pobres por igual (DiPuccio 44). Schmidhuber preserva, según DiPuccio, la estructura dramática de la comedia y el sistema hereditario-monárquico que recuenta la saga de tres generaciones de monarcas (Basilio, Segismundo y Américo). El título de la obra refleja el curso de la acción principal y Américo, el heredero más obvio, es el protagonista de las escenas (45). Sin embargo, la perspectiva histórica de los personajes tradicionalmente secundarios, Clarín el gracioso, su esposa Nicolasa, la cocinera, y el soldado, a medida que asumen el papel protagónico de los apartes, desarrollan el drama de los verdaderos herederos de Segismundo y del futuro de Polonia. Visual y verbalmente, espacial y temporalmente, sus acciones y palabras constituyen una trasgresión a los límites que establecen la línea divisoria en el teatro calderoniano entre personajes centrales y secundarios: "desde los márgenes del proscenio, los segundones revocan la ley de los primogénitos de las tablas, los nobles, y producen el drama de los verdaderos herederos de Polonia" (DiPuccio 4647 , traducción mía).

El concepto de primer y segundo orden se aplica también al papel dominante que la palabra ha gozado con respecto a la imagen en la codificación $\mathrm{y}$ transmisión del conocimiento en la cultura occidental. Para el pensamiento logocéntrico lo visual, como medio de conocimiento, ha sido ancilario y hasta prescindible - objeto de contemplación, silencioso e inmóvil, secundario a la dinámica articulación e importancia cultural del medio principal a través del cual comunicamos conceptos - el lenguaje y la palabra impresa. La relación de Los herederos de Segismundo a la escultura y a la fotografía, específicamente a las esculturas de Anselmo, el artista ficticio de la obra, y a la fotografía El arado de Roberto Ortíz Giacomán, subraya la importancia del arte visual como medio de conocimiento y la inspiración del arte verbal teatral en el arte visual (pinturas, fotografías, esculturas, y otras formas artísticas visuales) cuyas imágenes pueden considerarse una forma de teatralidad visual por su capacidad para representar las costumbres, los códigos y la estética de representación visual de un determinado periodo socio-cultural así como las tensiones que se establecen entre tradición e innovación. En la puesta en escena la obra dramática se completa con la semiótica de la imagen a través de la intersección del arte verbal y visual teatral, porque tanto el espacio teatral como el diseño de la escena, el vestuario y otras imágenes teatrales tienen un lenguaje dramatúrgico visual "que cuenta una historia que es parte de la obra" (Silva). 
En contraste con los textos ecfrástico que se articulan con frecuencia en ausencia de las imágenes que invocan, en las tablas los signos verbales están íntimamente relacionados con los signos visuales (el espacio escenográfico, el vestuario, el juego de luces, y los gestos de los personajes), relaciones que no deben considerarse transgresiones de un tipo de arte en el ámbito que le pertenece a otro sino el resultado de la colaboración artística de los que trabajan la palabra y la imagen (actores, directores, escenógrafos, diseñadores del vestuario, etc.), llevando a la escena el fruto de múltiples diálogos y perspectivas estéticas del mundo socio-cultural de la obra dramática. En la época presente, dominada por la imagen y la tecnología digital en que la escena visual se utiliza para ilustrar la instancia verbal en una suerte de inversión ecfrástica, como la designa Jay David Bolter, existe angustia respecto al futuro del libro como estructura de primer orden que se manifiesta en una colección de ensayos editados por Geoffrey Nunberg, con epílogo de Humberto Eco, titulado The Future of the Book. En el ambiente actual, dominado y subvertido por la ascendencia de la cultura visual es difícil definir, como observa Renate Brosch, los fenómenos culturales en términos puramente lingüísticos. Por consiguiente, es importante desarrollar métodos y modelos visuales que permitan descodificar las condiciones de percibir y de representar, e ilustrar cómo esas condiciones corresponden con la posición del sujeto, y con las relaciones del poder, en la sociedad (1-9).

En Los herederos de Segismundo el código meta-pictórico enmarca las imágenes que representan los valores hegemónicos de primer orden, y revela mediante la posición de los personajes en el espacio teatral cómo se perciben, son percibidos, representados y la relación de sus posiciones respecto al poder en la sociedad a que pertenecen. Los personajes secundarios juegan con el concepto de imágenes centrales y periféricas y advierten que es importante no fiarse de lo que se dice, desafiando al espectador a reflexionar sobre el lenguaje visual teatral (la escenografía, el vestuario, los gestos de los personajes) y su relación a las artes plásticas (la fotografía y la escultura) que critican el monopolio del poder del estado monárquico-cristiano y su indiferencia a la pobreza de la mayoría de los habitantes de Polonia.

Entre las prácticas llamadas artísticas de construcción visual (la fotografía, la pintura, la escultura), se incluye el uso del espacio escénico que también debe considerarse una forma artística. Como indica Juan Villegas el espacio escénico "tiene que ser pensado en su funcionalidad con respecto a la construcción del mundo y su significado en relación con el mensaje del mismo" (151). La utilización de esculturas y espacios escénicos en Los 
herederos de Segismundo cuestiona el arte y los espacios consagrados y legitimados cultural y teatralmente por los discursos hegemónicos. "Los planteamientos de Augusto Boal sobre el teatro del oprimido, y las prácticas de lo que llama 'teatro popular,' buscan la legitimación social y cultural de formas teatrales, algunas de las cuales incluyen la calle y la diversificación de los espacios escénicos" (Villegas 155). En Los herederos de Segismundo el uso del proscenio, la descripción ecfrástica de las esculturas del artista y de la fotografía El arado, así como los comentarios metateatrales de los personajes pobres respecto a la falta de espacios desde los cuales puedan ejercer y hacer valer sus derechos, constituyen actos de denuncia, transgresiones, semejantes a los planteamientos de Boal, debido a que el uso del espacio teatral de los apartes es una fuente tan comunicativa de la subversión, y diversificación, como las palabras de los personajes que ocupan ese recinto, cuyo objeto es tender un puente entre ricos y pobres, entre las escenas palaciegas y los apartes del proscenio.

Mediante un ingenioso diálogo metateatral lleno de humor e ironía Nicolasa, Clarín y el soldado demuestran la interrelación de lo verbal y lo visual, porque la palabra sólo puede ejercerse si se cuenta con un espacio ratificado por el poder. Su intervención en las escenas es mínima y para desempeñar el papel de los verdaderos herederos de Segismundo necesitan llamar atención a sus transgresiones (su ejercicio de la palabra en el espacio ancilario del proscenio) con el propósito de efectuar cambios que les permitan desempeñar papeles protagónicos en las escenas. Durante el último aparte Nicolasa y Clarín crean la ilusión de que tienen que concluir la obra que el dramaturgo dejó incompleta, y en el primer aparte los criados parecen actuar impropiamente, presentándose en las tablas antes de que la función empiece y hablando al público directamente, "fuera de los diálogos," como indica Nicolasa, marcados por el dramaturgo (48). Estos efectos se llevan a cabo mediante detalles aparentemente anacrónicos e incongruentes que irrumpen en la escena. Primero, el soldado entra y le dice a Nicolasa que los buscó a ella y a Clarín en todos los camerinos. Nicolasa borra la división entre actor y personaje cuando contesta que sólo los actores principales tienen camerinos, porque los que representan vidas como las suyas "siempre están cortos de diálogo y pobres de bolsa" (16). Luego, la voz impersonal del micrófono interrumpe el discurso de Nicolasa para anunciar la tercera llamada y el comienzo del drama. Las inversiones del espacio y el tiempo teatrales y el desdoblamiento de los personajes constituyen comentarios metateatrales que no permiten olvidar la teatralidad de la obra, y advierten que lo que aparece 
en el texto y en la escena pertenece a un sistema de signos teatrales que necesitan ser descifrados. En varias ocasiones los personajes de los apartes piden al público que aclaren el misterio de las formas mediante las cuales se expresa su historia y que no se fíen de lo que le digan los demás personajes. La obra requiere explícitamente que el lector y el espectador desempeñen un papel activo en la percepción de las dimensiones expresivas subyacentes en la preservación, inversión y trasgresión de los elementos espaciotemporales, visuales y verbales de la comedia puestos en escena textual y teatralmente y a cuestionar la "naturalidad" y la naturaleza de la las formas de representación establecidas en la cultura del siglo XVII.

W. J. T. Mitchell mantiene que no es necesario buscar los materiales visuales apropiados a una obra literaria en analogías históricas porque

lo visual es inherente al texto y se encuentra en el tejido de sus descripciones, en su 'visión narrativa, en los objetos representados, en los lugares, en las metáforas, en la disposición formal de sus partes, hasta en la tipografía, en el papel y en la encuadernación.... Si es difícil separar la textualidad de la pintura, es igualmente imposible mantener el arte visual fuera de la literatura." (Picture Theory 99 traducción mía)

Las observaciones de Mitchell son acertadas cuando se considera que la fotografía El arado de Roberto Ortiz de Giacomán, que no aparece en el texto, constituye, a través de la descripción ecfrástica, una de las imágenes centrales de la obra teatral. La imagen verbal del arado y pesadas piedras se basa en una escena agrícola que los monarcas y el joven príncipe Américo presencian diariamente por la ventana. Durante una conversación con Guillermo Schmidhuber descubrí que cuando iniciaba la escritura de la obra quedó fascinado cuando le tocó ver la foto, El arado, en una exhibición (“Arquelogía siglo XXI") y cuando escribía la obra le vino a la mente la metáfora del dolor humano como las piedras y los arados viejos, simbólica del tema central de la pieza: el talento de los campesinos para transformar el dolor humano en creaciones que alimentan el cuerpo y la esperanza, y la necesidad de reformar un sistema social que esclaviza a los pobres e ignora su capacidad estética e imaginativa. Cuando Américo, el futuro monarca de Polonia, afirma que el arte no es herencia de los pobres, el escultor contesta: ¡El hambre y el sufrimiento conducen a la belleza.! ¿No habéis visto desde la ventana de la torre cómo aran los labriegos la tierra dura y seca? Cuando el arado no hace surcos, le amarran piedras enormes para aumentar su peso; así logran que sus cuchillos hieran 
la tierra. El hambre y las tristezas son como esas piedras; logran hacer surcos en el espíritu, para que las semillas del ser germinen.

El arte verbal es inseparable del arte visual en Los herederos de Segismundo. Ambas formas artísticas denuncian los papeles y los espacios marginales a que están relegados los pobres por la falta de oportunidades económicas, culturales y sociales. Las obras del artista a quien los monarcas, Segismundo y su hijo Américo encargan las esculturas sirven de comentario meta-pictórico a las relaciones del poder en la obra. Como escultor de la corte, Maese Anselmo, refleja en sus esculturas la inestabilidad interior de un sistema indiferente a los pobres y amenazado exteriormente por una nación más fuerte. Como es de esperarse los monarcas destruyen las esculturas, porque las consideran una amenaza a su autoridad y a los valores establecidos. Segismundo y su padre Basilio en vez de crear un espacio para el diálogo con sus hijos usan formas visuales para acusar a sus hijos de traición: Basilio se basa en la posición de los astros y Segismundo en un icono que los monarcas rusos regalan al infante Américo. La falta de formas espacio-temporales para cultivar la libertad de expresión, y la aversión a ellas por los monarcas, se manifiesta en actos de violencia y represión. Segismundo da al traste con la estatua de su hijo. Con esta acción no sólo destruye simbólicamente a Américo sino también al mensaje de la plenitud del ser que Anselmo esculpió en la obra. Segismundo teme que su hijo y el mensaje de la estatua aboguen por una ideología subversiva a su persona y al orden imperante. Cuando Anselmo declara, "quiero deciros algo con esta piedra cuando la termine" (50), subraya que su obra de arte tiene un mensaje verbal para Américo. Segismundo tampoco considera la forma de la estatua un medio puramente visual sino un medio subversivo de comunicación. Esta actitud del monarca se manifiesta en las palabras que dirige a Anselmo:

Pero para que aprendáis a no ir más allá de las formas, os retiro mi mecenazgo y os castigo a la destrucción de la que llamáis vuestra obra maestra: (con sarcasmo) "La aventura del ser" (Américo levanta el rostro con expresión de gran sorpresa; telón lento). (92)

Segismundo considera la estatua una forma verbal con un mensaje capaz de poner en marcha un movimiento que conduzca al caos y a la ruina de sus propios intereses y los de Polonia. Espera que la destrucción de la estatua de Américo y el cautiverio de su hijo en la torre pondrán fin a las actividades nocivas a la hegemonía del poder. 
En el capitulo titulado "The Violence of Public Art: Do the Right Thing" W. J. T. Mitchell señala:

que lo que llama Habermas 'el modelo liberal de la esfera pública o la noción del arte público tal como la recibimos es inseparable de un espacio domesticado que se distingue de las dimensiones del espacio económico, privado y político. En ese espacio ideal los ciudadanos pueden contemplar un emblema transparente de su propia inclusividad y solidaridad y deliberar sobre el bienestar general, libre de coerción, violencia o intereses personales.... La inclusión de todo el mundo es el ideal ficticio de la noción clásica de la esfera pública; el hecho es que esa esfera se constituye por su rigurosa exclusión de ciertos grupos - esclavos, niños, extranjeros, los que no poseen propiedad, y (en particular) la exclusión de la mujer. (Picture Theory 378-79 traducción mía)

Las reflexiones de Mitchell nos hacen conscientes de que el arte, cuyo fin es denunciar la violencia y proponer cambios en el sistema, refleja inevitablemente la violencia que da origen a su propia manifestación en la esfera pública. Las esculturas del artista de la corte en Los herederos de Segismundo inevitablemente se perciben como provocación por su crítica a la violencia del orden hereditario monárquico. El cautiverio del infante Américo en la torre, no obstante su alta alcurnia, simboliza no sólo la violencia y la arbitrariedad del poder sino la suerte de todos aquellos, despojados o marginados de los privilegios reservados a la clase noble dirigente, que están sujetos a la falta de una autoridad legítima que ratifique el derecho a la hacienda, al honor, y a la movilidad social de la familia independientemente de clase, género y afiliación religiosa.

Otra escultura de Maese Anselmo representa a Cristo desnudo y no clavado sino sostenido por una multitud de manos en la cruz. Esta imagen no sólo critica la política del estado absolutista-monárquico-cristiano, sino que se relaciona a una tradición artística olvidada que es el tema del artículo de Leo Steinberg titulado "Sexuality of Christ in Renaissance Art and Modern Oblivion":

the first part of Steinberg's title refers to an enormous body of Renaissance painting in which the genitals of Christ are unambiguously displayed.... "The sexual component in the manhood of Christ was left unspoken, suppressed by the ethos of Christian asceticism, ultimately by decorum" (Steinberg 15). For the makers of images, however, the case stood otherwise. Steinberg cannot find reference 
to the matter in contemporary writing nor in the oblivion of subsequent literature (Steinberg 35) ... to an obviously widespread artistic practice, and a whole class of representation of extraordinary visual power, that for nearly two hundred years made the ostentatio genitalium a convention of the representation of Christ. (Citado en Gilman 15-17) La escultura del artista en Los herederos de Segismundo invita al lector y al espectador a reflexionar sobre la capacidad de la pintura para representar visualmente lo que la palabra es incapaz de mencionar verbalmente. Estas imágenes se convierten, como indica Steinberg, en textos primarios de lo que nunca se ha articulado. La escultura del artista en Los herederos critica la política teatral y artística a mi parecer "creada y 'naturalizada' por la Iglesia Católica que ha impuesto por siglos la recurrencia de imágenes, colores, personajes, posiciones humanas fácilmente identificables o determinantes en la teatralidad de la pintura, escultura, etc." (Villegas 170). La imagen de Cristo desnudo en la escultura de las puertas de la catedral que presenciamos ecfrásticamente a través de los comentarios de los personajes constituye una trasgresión verbal y visual respecto a la iconografía tradicional, desafiando a Américo a establecer un nuevo rumbo para el país, porque durante su reinado, Polonia ha logrado la comodidad material también para los pobres pero no ha encontrado ni la felicidad ni la paz. Américo se duerme y sueña la historia inscrita en el lenguaje de las imágenes de la puerta de bronce que abre y cierra la catedral. Es una historia en la que lo verbal se complementa con lo visual y en la que el ser humano se ve reflejado en la imagen del otro (el hombre común representado por Cristo es contemplado como artista, y por extensión, como estadista, obispo, científico, etc.), instándose a los que gobiernan y a los que son gobernados a remover los obstáculos (las manos) que impiden la formación de una comunidad basada en la aventura del ser, la identidad individual y la plenitud socio-cultural de Polonia. El sueño de la puerta de bronce prefigura el final de la obra, puesto que los hijos de Nicolasa y Clarín, que gracias a la astucia de su madre, han recibido la mejor instrucción asequible en el reino, heredan el gobierno de Polonia.

ANSELMO: (Aparece mirar la obra) Mi puerta de bronce que abre y cierra la catedral, guarda un secreto. Entre la multitud de figuras, al otro lado de Francesca de Rimini y de Einstein, está la figura de un adolescente.

AMÉRICO: (extasiado) ¡Es maravillosa! ¡Soy yo! Es la aventura de mi ser! ¡Ahí está Cristo; tiene vuestro rostro! 
ANSELMO: (alucinado) ¡Cristo no está clavado, sino sostenido en la cruz por una multitud de manos; los clavos somos todos!

AMÉRICO: ¿Por qué lo pusiste desnudo?

ANSELMO: (mira con fijeza a Américo). Por una sola razón: para evitar la guerra.

AMÉRICO: (con ira) ¡Anselmo, no bromeéis!

ANSELMO: Si no entendéis mi mensaje no hay salvación; el único camino será la guerra.

AMÉRICO: (muy conmovido) ¿Y si le rezo a ese Cristo desnudo? ANSELMO: Quizás entonces hay un poco de esperanza. (215-16)

La guerra que el escultor desea evitar remite a la revuelta popular que se va formando en el país, durante la cual Nicolasa siembra la agitación en el palacio que ayuda a poner fin a los diez años de prisión del hijo de Segismundo, y a coronarlo para evitar una invasión rusa. La cocina se convierte en un espacio en el contexto de la obra que no sólo sirve la función tradicional de la preparación de alimentos, sino de base para la preparación de cambios sociales. Los cambios que Nicolasa inicia y defiende a lo largo de la obra inspiran al Maese Anselmo a verla como una figura heroica, digna de sus creaciones artísticas, cuyo fin es expresar los esfuerzos del ser humano para alcanzar la plenitud de su capacidad social, espiritual, intelectual y artística. Este es el mensaje que anhela proyectar en sus obras: en la escultura de Nicolasa, anteriormente en la del busto del infante Américo y finalmente en las formas de la escultura de la catedral. De las tres sólo queda intacta la de la cocinera al final de la obra.

Veinte años después de su coronación, Américo destruye las esculturas hechas por Anselmo cuando tiene que enfrentarse a una crisis personal y política. Su hijo está muriéndose de una enfermedad que la ciencia no puede curar y Segismundo, cuya mente ha sido asolada por la senilidad, yace en su lecho de muerte. Moscovia se coaliga con los pueblos dominados por Américo, y se prepara para atacar Polonia por mar y por tierra. Paralizado por los cuidados y las aflicciones de ánimo y el peso de la corona, Américo reacciona como su padre y abuelo bajo circunstancias semejantes: busca soluciones en el absolutismo monárquico, y amenaza expulsar y destruir a las personas y objetos de su reino que le inquietan y no están en armonía con los resultados que desea. Dirige con gran ira las siguientes advertencias a Clotaldo, el científico de la corte: " $i Y$ si tus 'matemáticas sutiles' no pueden salvar a mi hijo, te borraré de la historia!" Y al obispo le dice: "Rogad a Dios que el infante recobre la salud; si no, olvidaos de Polonia, porque yo haré que Polonia 
se olvide de vos" (245). El odio dirigido a Anselmo y a la escultura se debe a que Américo se percibe retratado desde una perspectiva poco halagadora. Cuando el obispo le pregunta a Américo qué es lo que le incomoda en la cornisa, el iracundo monarca contesta: "Vos nunca entenderíais. (a Anselmo) ¡Maldito! ¿Cómo os atrevisteis a parodiar "La aventura del ser”? Mi aventura del ser! ¡Yo no soy así! ¡Soy mucho más! ¡Yo soy tu rey! ¡Soy la cumbre de la historia, y vos osáis burlaros de mí!" (250). El estado de ánimo de Américo le hace atribuir a la estatua una "mirada" que le incomoda. Las palabras de Américo a Anselmo sugieren que la mirada que le devuelve la figura hecha a su imagen frustra sus deseos como lo había hecho con su padre la estatua destruida veinte años antes: "¡Mi padre destruyó la primera versión, y no aprendisteis la lección!" (250). La lección consiste en usar "el silencio" estratégicamente y no ir más allá de las formas halagadoras al poder, cuya función es ocultar su sistema de signos ideológicos. Es decir: crear la ilusión de naturalidad para no llamar la atención al "lenguaje y a la estructura de valores e intereses que representan 'la realidad' del poder" (Mitchell, Iconology 4).

La pregunta surge naturalmente, según Mitchell, “¿si el arte público es inherentemente violento o una provocación a la violencia? ¿Es la violencia parte de un monumento en el momento de su concepción? o ¿es la violencia simplemente un accidente que le sucede al arte público o un accidente que siempre está a punto de realizarse?" (Picture Theory 378). De acuerdo al crítico, la mayoría del arte público es mucho más que la sempiterna posibilidad de un accidente:

La mayor parte del arte público mundial - memoriales, monumentos, arcos triunfales, obeliscos, columnas, y estatuas - tienen una referencia directa a la violencia en la forma de guerra o de conquista. Desde Ozymandias a César a Napoleón a Hitler, el arte público ha servido como una forma de monumentalizar la violencia, y nunca con mayor impacto como cuando representa al vencedor como un hombre pacífico que impone el código napoleónico o la pax romana en el mundo. (Picture Theory 378 traducción mía)

Irónicamente, Américo es el que aprende la lección cuando el curso inesperado de los acontecimientos hiere su conciencia y tiene que elegir entre el despotismo engendrado por la parálisis del miedo, del sufrimiento y de la ira o arriesgarse a actuar, sin garantías de éxito, de una manera que responda a su sentido de dignidad y al de su pueblo. Después de la muerte de su hijo y de su padre, Américo experimenta un cambio de actitud. Deja de 
exigir respuestas a sus dilemas, y toma la responsabilidad de declarar la guerra contra Moscovia, a pesar de la inestabilidad de su situación personal y política. ${ }^{2}$ Antes de partir para la guerra, Américo indica que ahora comprende lo que Anselmo ha querido comunicarle por muchos años cuando le dice: "Aquí en la torre, cuando los arados son viejos y no surcan la tierra, los labriegos les amarran grandes piedras... para que abran la tierra; así son las tristezas, ¿Verdad Maese Anselmo? Tú me lo expresaste hace muchos años" (275). Aunque las esculturas han sido destruidas, su mensaje, como el de las imágenes verbales del arado, quedan grabadas en la mente del monarca, y la historia que cuentan se despliega durante el curso de los años en su conciencia. El arte visual y las estructuras espaciales no se perciben simplemente como figuras estáticas. Estas cambian de acuerdo al ángulo y marco temporal desde el cual se contemplan. La torre, por ejemplo, sirve de prisión e instrumento de tortura para Segismundo y Américo en su juventud, $\mathrm{y}$, en momentos de crisis durante los años de la madurez, les sirve de claustro, de refugio y de atalaya. Inversamente, las palabras no son aprehendidas exclusivamente en el tiempo, porque las formas visuales son partes integrantes de la experiencia verbal: la relación del dolor a la expansión del espíritu se ilustra mediante la imagen de la labranza, una escena frecuentemente vista desde la ventana de la torre.

La representación ecfrástica de las esculturas y del arado refleja los discursos que Los herederos de Segismundo pone en escena visual y verbalmente, proponiendo que imágenes y discursos no son radicalmente opuestos ni mutuamente exclusivos, y que las divisiones establecidas entre textos e imágenes se hallan muchas veces invertidas de intereses, valores, pensamientos y creencias (de ideologías) que producen relaciones asimétricas de poder entre nobles y villanos, entre imágenes de primer y segundo orden, entre textos e imágenes.

El carácter meta-representativo de la descripción ecfrástica nos permite re-negociar, como indica Renate Brosch, las relaciones entre imágenes y textos:

Ekphrastic texts participate in the redefintition of the visual against the older authority of the verbal because their doubled system of signification addresses the verbal and the visual faculties. Therefore ekphrasis can have particularly useful historical investigations of changes in perception, iconographies and textual representation. (56) 
En vista de que el lenguaje verbal ha sido el principal medio de comunicación en nuestra cultura, para verdaderamente mantener un diálogo entre texto e imagen es necesario desarrollar sistemas que permitan descodificar patrones visuales culturales. Nuevos métodos interdisciplinarios desarrollados por "visual culture"3 y otras disciplinas que forman parte de "cultural studies" conceden igual importancia a lo visual y a lo verbal, estableciendo nuevas pautas metodológicas y programáticas para sus disciplinas que permitan determinar el papel de lo visual en el campo cultural a que pertenece.

Como se ha observado, en Los herederos de Segismundo lo visual funciona en concierto dinámico con lo verbal para complicar y desafiar las normas tradicionales de ver, ser visto y representar, cruzando barreras sociales, estéticas, visuales y verbales, y proporcionando nuevas maneras de formar identidades. Se espera que el predominio de la imagen visual en nuestra época conduzca a percibir, representar, comunicar y codificar nuestro conocimiento del mundo no sólo a través de palabras y conceptos verbales sino mediante imágenes y conceptos visuales. Es también de esperar que la formación de nuevas disciplinas que equilibren la polémica entre palabra e imagen incontaminada, sirvan de bases para establecer fértiles diálogos interdisciplinarios, nuevas identidades y para re-negociar las asimetrías de los sistemas binarios occidentales.

\section{Oswego, State University of New York}

\section{Notas}

' En abril, 2005, presenté un ensayo en el que me enfoqué en Los herederos de Segismundo titulado "Transgresiones ecfrásticas en el teatro mexicano contemporáneo" que tuvo lugar en el simposio de teatro latinoamericano, Conference on Latin American Theatre Today: Festival and Symposium, en la Universidad de Connecticut en Storrs. Una versión abreviada del artículo fue presentada inicialmente en una sesión dedicada a la obra de Guillermo Schmidhuber en las 4tas Jornadas Internacionales de Teatro Latinoamericano en julio 1996 en la ciudad de Puebla, México. Guillermo Schmidhuber estuvo presente para la ocasión, y durante una conversación con el dramaturgo descubrí que se inspiró en una fotografía para crear la imagen del arado y las piedras en la obra. En respuesta a mi petición, Guillermo Schmidhuber me envió una imagen de la fotografía por correo electrónico el 8 de mayo de 2003 y un breve mensaje: "la foto que me inspiró esas palabras en Los herederos de Segismundo: arados con pesadas piedras... es de Roberto Ortiz, fotógrafo de Monterrey, México, y la tomó el 21/9/77. Buscando la foto, encontré el manuscrito original escrito a pluma, y gocé leyéndolo y viendo como di creación a esa pieza, trabajando con gran rapidez y en muchas escenas a primera pluma." 
Unas semanas antes de enviarme la misiva electrónica del 25 de agosto de 2003, Guillermo Schmidhuber obtuvo los derechos de autor y una copia digitalizada de la fotografía $E l$ arado que me mandó por correo aéreo el 22 de agosto de 2003. En la misiva electrónica Schmidhuber proporciona importante datos sobre Los herederos y el papel de las artes visuales en sus obras. Información que puede ser pertinente de Los herederos:

Los herederos, una obra teatral dedicada al dramaturgo español Buero Vallejo, fue estrenada en el Festival Cervantino, el 28 de abril de 1981, en el Teatro Principal de Guanajuato, México, bajo la dirección de Sergio García y la Producción de Profesionales del Teatro de Nuevo León (PREOTAC), cuyo presidente era Luis Martín Garza. Ganó los siguientes premios: Premio Nacional de Teatro del Instituto Nacional de Bellas Artes (INBA), 1980; Premio Ramón López Velarde del Gobierno de Zacatecas, 1980; Finalista en el premio Tirso de Molina de Madrid, 1980. Se ha editado tres veces en México: 1) Editorial Oasis, 1982. Con nota de forros de Fernando de Ita; 2) Gobierno del estado de Nuevo León, INBA, FONAPAS, 1982, con un prólogo de Rafael Solana; 3) En el volumen II, de Trece apuestas al teatro. Gobierno del Estado de Colima, Universidad de Colima y CONACULTA, 1999: 43-108. La importancia de las artes plásticas para Schmidhuber ha sido patente en que en muchos de sus libros hay una portada de un pintor afamado mexicano. Es viñeta cuando el pintor la hizo para esa edición: Por las tierras de Colón, copia de pintura de José Clemente Orozco; Trece apuestas al teatro, gráfica de Gabriel Fernández Ledesma; Nuestro Señor Quetzalcoált, dos viñetas de Manuel Felguérez; Lacandonia, viñeta original de Alberto Beltrán; Sor Juana dramaturga, viñeta de Alberto Beltrán; Felicidad instantánea, cuatro viñetas originales de Rafael Coronel; Los herederos de Segismundo, una viñeta de Juan Soriano; Los entes teatrales, una viñeta de Rafael Coronel; El ojo teatral, una viñeta de Rafael Coronel; La catedral humana, viñeta de Jorge González Neri. Guillermo Schmidhuber también tocó el papel del artista en El día que Monalisa dejó de sonreir, que presenta en escena el día que murió Leonardo da Vinci.

2 La tesis de Susana L. Fischer en su ensayo titulado "This Thing of Darkness I/ Acknowledge Mine: Segismundo, Próspero, and Shadow" sobre la libertad de Segismundo en La vida es sueño es la tesis que más se asemeja al sistema significativo del punto decisivo en la vida de Américo en Los herederos de Segismundo. Fischer arguye que en La vida es sueño la libertad de Segismundo "demanda la activa participación de su parte aun en vista de la incertidumbre (157), y "su libertad interior sólo puede resguardarse si permite que otros sean libres" (160).

3 "Visual culture has been redefined from a term used by people working in art history, film and media to a more encompassing term of interdisciplinary reference, including such heterogeneous subjects as fashion, design, architecture, archaeology, advertising and television, visual culture is an integrated field of inquiry which generates questions previously obscured by the divisions and boundaries between academic specialisms... 2002 saw the founding of the London-based Journal of Visual Culture with cultural mediators like Mieke Bal and Martin Jay on the editorial board. This increased acceptance of 'visual culture' as an interdisciplinary field of study has resulted in a reconceptualisation of images, by rejecting Western culture's tradition of consistently privileging the word over the image. This hegemony of the text is now being contested as a result of 'visual culture' existing as a new field of theoretical inquiry. Visual culture studies investigate pictorial as well as textual models of the world. Thus what is termed 'Visual Culture' is no longer, as an older art history saw it, a study of pictures and their semiotic or iconographic interpretation, but a resolutely interdisciplinary study determining the role of the visual in the wider field of culture to which it belongs." (Renate Brosch 1-4). 


\section{Obras citadas}

Brosch, Renate."Visual Culture" German Association for the Study of British Cultures $<$ http://www.ruhr-unibochum.de/britcult/DOFPBrosch.htm $>2005$.

DiPuccio, Denise M. "Burdensome Heritages in Los herederos de Segismundo." Chasqui 19.2 (1990): 43-50.

Fischer, Susana L. "This Thing of Darkness I/Acknowledge Mine: Segismundo, Próspero and Shadow." de Armas, Frederick A. (ed.) The Prince in the Tower: Perceptions of La vida es sueño. Lewisburg: Bucknell UP, 1993: 147-64.

González-Pérez, Armando. Presencia negra: teatro cubano de la diáspora: antología crítica. Madrid: Editorial Betania, 1999.

Gilman, Ernest B. “Interart Studies and the 'Imperialism' of Language.” Poetics Today, 10.1. Art and Literature I. (Spring 1989): 5-30.

Heffernan, James A. W. Ekphrasis and Representation. New Literary History 22.2 (Spring 1991): 297-316.

Mitchell, W.J.T. Iconology: Image, Text, Ideology. Chicago and London: U of Chicago $\mathrm{P}, 1986$.

Mitchell, W.J.T. Picture Theory. Chicago and London: U of Chicago P, 1994.

Nunberg, Geoffrey ed. The Future of the Book. Afterword by Umberto Eco. U of California P, 1996.

Schmidhuber de la Mora, Guillermo. Los herederos de Segismundo. Mexico: Fonapas, 1982.

Silva, Sonia. "Dora García: el vestuario debe contarte una historia, pero hay que agregarle el lenguaje teatral para que pueda hacerlo." La cultura: Sala de prensa. <.http://www.cnca.gob.mx/cnca/nuevo/2001/diarias/abr/300401/ dramatur.html $>30$ abril 2001.

Van Allen, Adrian. "The Fiend of Hypertext or The Visualization of Inert Knowledge:

Cult of the Word." <http://pages.slc.edu/ ebj/minds/student_pages/adrian/ vis13.html $>2005$.

Villegas, Juan. Para la interpretación del teatro como construcción visual. Colección Teoría 2. Irvine: Gestos, 2000.

Zatlin, Phyllis. "Ekphrastic Theater and the Contemporary Spanish Stage." Journal of Interdisciplinary Literary Studies 2.2 (1990): 201-13. 